\title{
The Relationship between the Hair Cycle and the Age or Daily Body Weight Gain in Rabbits
}

\author{
Masahiro TAKEYOSHI and Masao KODA \\ Hita Research Laboratories, Chemical Biotesting Center, Chemicals Inspection \& Testing \\ Institute, 3-822 Ishii-machi, Hita-shi, Oita 877, Japan
}

(Received 28 January 1994/Aceepted 21 April 1994)

\begin{abstract}
The relationship between the hair cycle and the age or daily body weight gain (daily gain) in rabbits was investigated. A survey of the ages of rabbits used for the dermal toxicological studies in our laboratories over the last 4 years was done, followed by an experiment to confirm the results of the survey. Although there seemed to be no relationship between the hair cycle and the daily gain, the results showed that the hair cycle was closely related to the age of the animal, and the animals in the telogen stage may be obtained efficiently at about 17 wks of age.-KEY WORDS : age, daily gain, hair cycle, rabbits
\end{abstract}

The skin of rabbits is widely used for evaluating the dermal toxicological and pharmacological properties of chemicals. Hair growth occurs in a cycle known as the hair cycle, which consists of three stages: a growing period (anagen, Fig. 1A), a resting period (telogen, Fig. 1B) and a transient period (catagen) [3]. The sensitivity of the skin is known to be affected by the hair cycle. In rabbits, skin in the anagen stage is reported to be more sensitive to irritants than skin in the telogen stage [2] and skin reaction with skin in the catagen stage are not highly reproducible [1]. Moreover, with skin in the anagen stage, it is difficult to observe skin reactions to irritants because of the reddish skin color and hair growth. Therefore, we usually use rabbits in the telogen stage for dermal toxicological studies in order to get reproducible data.

In this study, the relationship between the hair cycle and the age of animals or daily body weight gain (daily gain) was investigated in order to the aim of selecting animals in a telogen stage efficiently.

First, a survey of the age of rabbits used for the dermal toxicological studies in our laboratories over the last 4 years was done. For various kind of studies, we purchased $540 \mathrm{rab}$ - bits (395 males and 145 females), among which 201 (159 males and 42 females) were used for the dermal toxicological studies. All of the rabbits were of the New Zealand White breed and were obtained from Kitayama LABES Ltd. The ages of the rabbits used for the dermal toxicological studies were distributed within the range of 14 to 32 wks. A large number $(36 \%)$ of the rabbits were 17 wks of age (Fig. 2). This suggested that a large percentage of rabbits would be at the telogen stage at about 17 wks of age.

We then conducted an experiment to confirm the above results. For this, 5 male New Zealand White rabbits, 5 wks of age, were obtained from the same breeder, and the stage of the hair cycle was observed every week after removal of hair from the back between 5 and 20 wks of age. The clipped area of the skin cut out from the photograph taken at the time of observation was weighed, and the percentage weight of skin in the telogen stage cut out from the photograph relative to the weight of the clipped area was calculated as the telogen index (TI) . The mean TI of the rabbits exceeded $80 \%$ between 15 and 18 wks of age. During this period, all animals showed high TI values (82 98\%) (Fig. 3). Although one of the 5 


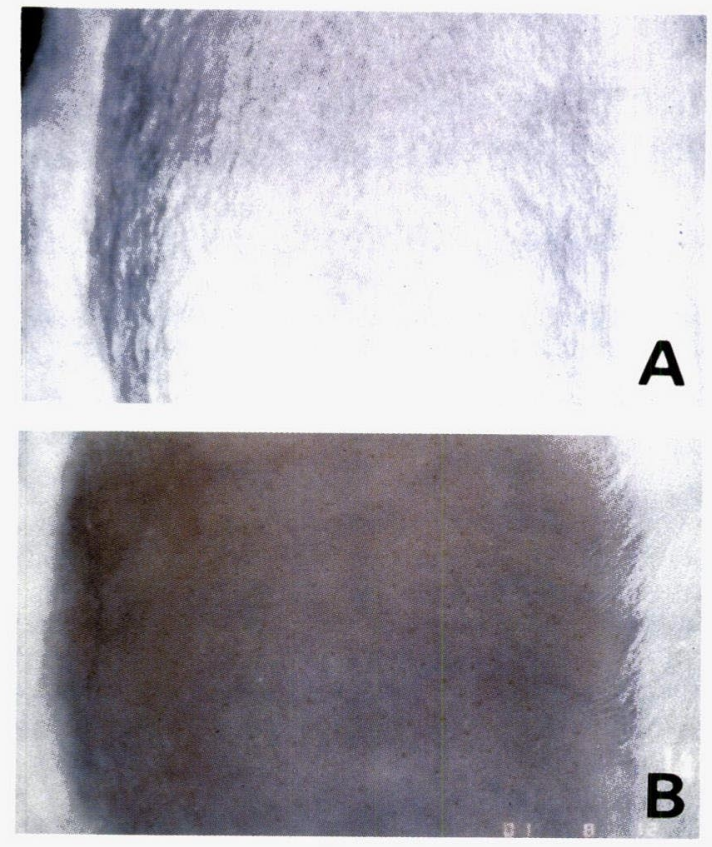

Fig. 1. Skin of rabbit at the anagen stage (A) and the telogen stage (B) 7 days after clipping free of hair

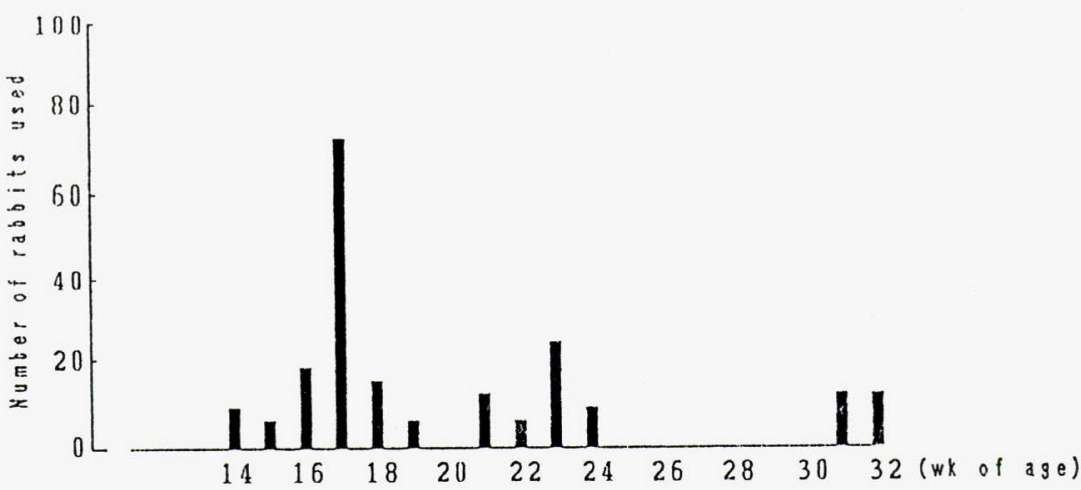

Fig. 2. Number of rabbits used in dermal toxicological studies and their ages

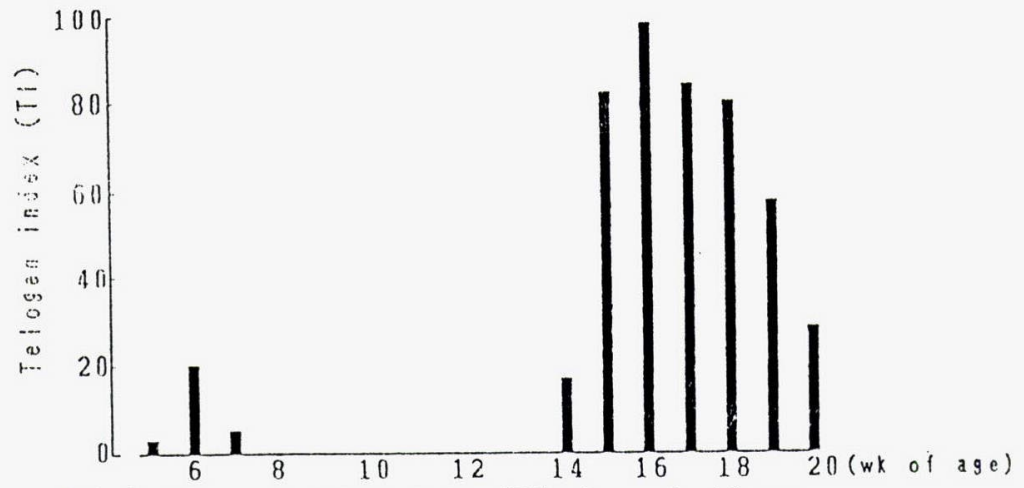

Fig. 3. Changes in telogen index (TI) observed with age 


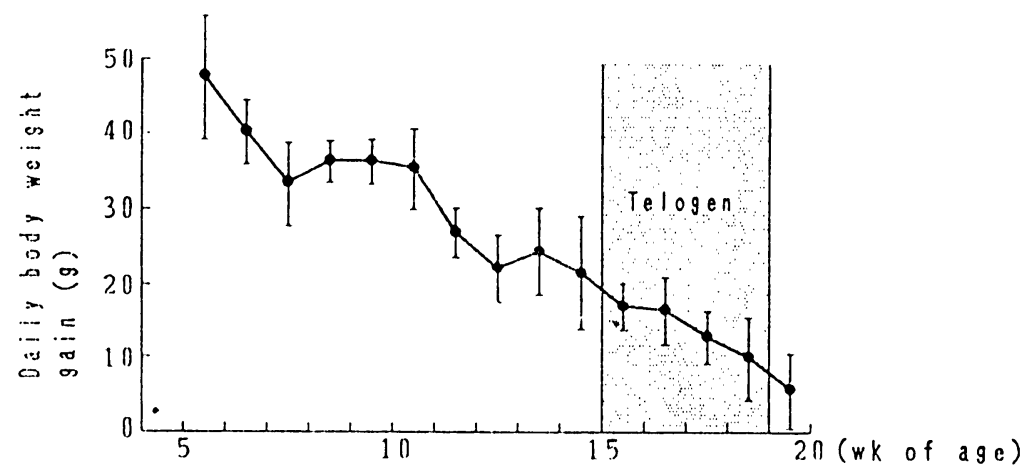

Fig. 4. Changes in daily body weight gain with age. Each value represents the mean of 5 animals and the standard deviation.

animals showed a TI value of $100 \%$ at $6 \mathrm{wks}$ of age, the other animals showed TI value of $0 \%$.

Daily body weight gain was calculated every week, and showed a gradual decrease with increasing age (Fig. 4). There appeared to be no relationship between TI and daily body weight again.

These results show that the hair cycle is closely related to the age of the animal, and the animals in the telogen stage may be obtained efficiently at about 17 wks of age.

\section{References}

[1] Ikeda, Y., Horiuchi, S., Yoshimoto, H., Furuya, T., Kawamata, K., and Kaneko, T. (1970), IYA. KUHIN KENKYU, 1, 23-27

[2] Morikawa, F. (1972), Jpn.J. Dermatol ., 82, 794-800

[3] Muller, G. H., Kirk, R. W., and Scott, D. W. (1983). In Small Animal Dermatology (3rd edition), pp 33-37, W. B. Saunders Co., Philadelphia

\title{
ウサギの毛周期と週齢および一日増体重との関係
}

\author{
武吉正博・江田雅雄
}

財団法人化学品検査協会化学品安全センター日田研究所

ウサギの毛周期と週粭および一日増体重の関係につ いて検討を行った。当研究所で実施した皮虐毒性試験 に使用したウサギの週秢について過去 4 年間の集計を 行うとともに, 調査結果を裏づけるための実験を行っ
た。その結果, ウサギの毛周期と一日増体重の間に関 連性は認められなかったが, 毛周期は動物の週秢と密 接に関連し，休止期の皮虚を有する動物は 17 週秢前後 の動物から効率的に得られるものと思われた。 